\author{
Anna Ziółkowska \\ Uniwersytet Mikołaja Kopernika w Toruniu \\ anna_z@doktorant.umk.pl
}

\title{
KILKA StÓW O TYM, DLACZEGO NIE POWINNO SIĘ TEUMACZYĆ BAŚNI BRACI GRIMM POPRZEZ JĘZYK TRZECI
}

DOl: http://dx.doi.org/10.12775/RP.2016.008

\section{Wstęp}

Tumaczenie rozumiane jest zazwyczaj jako przekazywanie niektórych treści wyrażonych w L1 (język źródłowy) na L2 (język docelowy)" (Sumera 2000: 527) (tłum. A.Z.). Czasami jednak zdarza się, że w proces przekładu angażowany jest tak zwany langue pivot, czyli język trzeci, zwany także pośrednim. Tłumaczenie poprzez język pośredni jest uzasadnione tylko w określonych przypadkach, na przykład jeśli chodzi o przekład tekstów z języków rzadkich i egzotycznych. Trudno znaleźć sensowne uzasadnienie przekładu baśni braci Grimm na język polski poprzez języki pośrednie, jakimi są rosyjski, angielski i węgierski. Język niemiecki jako język naszych sąsiadów nie wydaje się na tyle egzotyczny, aby trzeba było napisaną nim literaturę tłuma- 
czyć na nasz język ojczysty poprzez inne języki. O ile w miarę uświadomiony jest fakt, że wykorzystanie języków pośrednich w przekładzie tekstów specjalistycznych, np. prawniczych, może wbrew intencjom tłumacza spowodować błędy w tekście docelowym ${ }^{1}$, o tyle nie zauważa się konsekwencji, jakie niesie ze sobą tłumaczenie literatury pięknej poprzez język trzeci. Celem niniejszego artykułu jest uświadomienie polskim czytelnikom i adeptom tłumaczenia błędów wynikających z takiego działania.

\section{Krótka historia powstania Kinder- und Hausmärchen}

Pełne wydanie Kinder- und Hausmärchen, które liczy 200 baśni i 10 legend (Deutsche Sagen), w tradycji niemieckiej nazywane jest Große Ausgabe, czyli Wielkie wydanie. Oprócz niego istnieje jeszcze zawierające 50 baśni Kleine Ausgabe, tj. Małe wydanie. Pierwszy tom baśni ukazał się w grudniu 1812 roku, drugi - trzy lata później. Rok 1819 roku przyniósł drugie wydanie obu tomów baśni, poszerzone o kilka bajek z poprawkami wprowadzonymi przez Wilhelma Grimma. Małe wydanie pojawiło się w roku 1825 i zawierało 50 baśni wybranych przez Wilhelma z Wielkiego wydania, uznanych przez niego za najbardziej odpowiednie dla dzieci. Za życia Grimmów ukazało się w Niemczech jeszcze siedem wydań - ostatnie w 1857 roku i to ono stanowiło źródło przekładów na języki obce. Powszechnie wiadomo, że baśnie ze zbioru Kinder- und Hausmärchen nie są własną twórczością braci Grimm, ponieważ obaj byli tylko ich zbieraczami, co dobitnie podkreśla Dorota Simonides w artykule Jakub $i$ Wilhelm Grimmowie a folklor polski: „dowodów na to, że bracia istotnie zbierali w terenie swe bajki, jest sporo i nie ma potrzeby udowadniać tego" (Simonides 1989: 31). Grimmowie zainspirowani twórczością literacką Clemensa Brentano i Achima von Arnima oraz współpracą z poetami przy zbiorze Cudowny róg chłopca wysłuchali funkcjonujących w przekazie ustnym opowieści ludowych i spisali je. Nie do końca jednak prawdziwe jest powszechne wyobrażenie o wędrówce braci przez kraj w poszukiwaniu ludowych opowieści, bo wiele źródeł wskazuje na to, że mieli oni swoich informatorów, którzy zbierali dla nich ustne przekazy. Często nie były to, jak powszechnie się uważa, osoby z ludu, ale przedstawiciele bogatego

${ }^{1} \mathrm{O}$ przekładzie poprzez języki pośrednie niemiecki i angielski umów prawnych w parze chiński-polski oraz negatywnych konsekwencjach takiego przekładu pisała Joanna Grzybek (por. Grzybek 2015: 67-79), błędom wynikającym ze stosowania języków pośrednich poświęcił swój artykuł także Jacek Pleciński (por. Pleciński 2015: 139-150). 
i wykształconego mieszczaństwa. Pieciul-Karmińska pisze, że „W większości były [to] kobiety i to bynajmniej nie przedstawicielki ludu" (Pieciul-Karmińska 2011: 81). Wśród typowo niemieckich baśni ${ }^{2}$ pojawiły się również baśnie pochodzące $z$ Francji, dlatego że opowiadającymi je często były francuskie nianie i guwernantki. Potwierdza to Monika Woźniak: ,jak wykazały badania źródeł za pośrednictwem bajarek francuskiego pochodzenia przeniknęły do zbioru Grimmów prawie wszystkie baśnie Charles’a Perrlauta" (Woźniak 2011: 60). Z każdym kolejnym wydaniem, pod wpływem przyjaciól, recenzentów i wydawców, bracia Grimm wprowadzali coraz więcej zmian. Simonides twierdzi, że „można śmiało zaryzykować pogląd, iż najwierniejsze było pierwsze wydanie, kolejne ulegały przeróbkom pod naciskiem recenzentów i przyjaciół”, i dodaje, „że porównanie wydania pierwszego z siódmym ukazuje duże zmiany" (Simonides 1989: 30). Największych przeróbek dokonał sam Wilhelm Grimm, wprowadzając modyfikacje polegające na mnożeniu szczegółów, rozwijaniu dialogów, dodawaniu przysłów i rymowanek oraz nastrojowemu przedstawianiu fabuły. Przede wszystkim jednak poprawki obejmowały usunięcie lub przeformułowanie fragmentów dotyczących aluzji seksualnych i przemocy fizycznej, ponieważ późniejsze wydania baśni przekształcono w literaturę czysto dziecięcą. Ponadto baśnie wzbogacono o treści religijne (por. Seitz 1984: 59). Wilhelm jako poeta nie potrafił oprzeć się pokusie wprowadzania zmian upiększających i rozbudowujących fabułę baśni, czemu całkowicie przeciwny był Jakub, doceniający prostotę tekstów i postulujący pozostawienie ich w pierwotnej formie. Simonides pisze, że Jakuba drażniły zmiany wprowadzane przez Wilhelma, ubolewał nad wtrącaniem się w teksty i miał świadomość tego, że każda ingerencja jest niedopuszczalna z punktu widzenia badawczego (por. Simonides 1989: 30-31). Ponadto badaczka podkreśla, że nie należy oceniać baśni ze współczesnego nam punktu widzenia i narzekać na wprowadzone zmiany, ale trzeba pamiętać o epoce i warunkach powstania dzieła. Uważa, że chcąc zrozumieć wielkość i autentyczność zbioru Kinder- und Hausmärchen, trzeba sięgnąć do epoki Grimmów. „I tylko na tle epoki, na tle wcześniejszych lub równoczesnych Grimmom osiągnięć możemy badać wielkość tego niezwykłego dzieła" (Simonides 1989: 25). O niesłabnącej popularności zbioru może świadczyć również fakt, że przetłumaczono go na ponad 160 języków, a w 2005 roku wpisano na

2 Braciom Grimm bardzo zależało na tym, aby do zbioru trafiły „bajki autentyczne, rodzime i niemieckie” (Simonides 1989: 31), ponieważ uważali, że zebrane przez nich baśnie są swego rodzaju narzędziem mającym odbudować nadwątloną wojnami napoleońskimi świadomość i kulturę narodową Niemców (por. Waksmund 2000: 163, Krysztofiak 1999: 149). 
Światową Listę Dziedzictwa Narodowego UNESCO (por. Pieciul-Karmińska 2011: 80).

\section{Historia przekładów Kinder- und Hausmärchen na gruncie polskim}

Z badań wrocławskiego germanisty Marka Hałuba (1986) dotyczących recepcji zbioru Kinder- und Hausmärchen w Polsce wynika, że rozpoczęła się ona dość późno, ponieważ pierwsze pojedyncze przekłady pojawiły się na ziemiach polskich dopiero pod koniec lat sześćdziesiątych XIX wieku. W przeciwieństwie do Polski w większości krajów europejskich przekłady wydano jeszcze za życia obu braci, „między innymi w Danii (1816), Niderlandach (1820), Anglii (1823), Szwecji (1824), Francji (1830); po śmierci Wilhelma w 1859 roku Jakub doczekał się jeszcze debiutu zbioru na Węgrzech (1861) i w Rosji (1863)” (Hałub 1998: 227). W przypadku języka polskiego „na początku były to tłumaczenia pojedynczych tekstów: 1865, Zając i jeż Der Hase und der Igel; 1880, Śnieżna Różyczka Sneewittchen; 1880, Jaś i Małgosia Hänsel und Gretel" (Grzywka 2007: 43). Licznie pojawiały się pojedyncze baśnie lub zbiory kilku, kilkunastu baśni w wyborze. Trudno nazwać je jednak przekładami, zasługują one raczej na miano adaptacji, mimo że polski czytelnik może być tego nieświadomy, co jasno artykułuje Maria Krysztofiak w książce Przekład literacki a translatologia: „Czytelnik, literaturoznawca bądź pedagog polski nie zawsze sobie w pełni uświadamia, że w swej praktyce lektorskiej nie posługuje się tekstami baśni Grimmów, a jedynie spreparowanymi przez wydawców i tłumaczy nieadekwatnymi polskimi kopiami tych baśni” (Krysztofiak 1999: 174). Pierwszy większy zbiór baśni zatytułowany Baśnie dla dzieci i młodzieży, który liczył 16 bajek, został przetłumaczony w 1895 roku przez Cecylię Niewiadomską. Rok później ukazał się pierwszy pełny przekład z oryginału z 1857 roku, dokonany przez Zofię Antoninę Kowerską. Inicjatorem tego przedsięwzięcia był znany polski folklorysta Jan Karłowicz, który w Bibliotece Wisty w tomach 14 i 15 wydał Bajki domowe i dziecinne zebrane przez braci Grimm (por. Simonides 1989: 43). „Po pierwszym polskim przekładzie, Baśnie bardzo szybko trafily do rąk dzieci. Szczególnie na tle ówczesnych moralizatorskich powiastek dla dzieci zachwyciły bujnością fantastyki i przyciągały małych czytelników. [...] Stały się u nas najpopularniejszym utworem dla dzieci" (Białkowska 1971: 22). O popularności zbioru braci Grimm może świadczyć liczba wydawanych baśni w kolejnych latach i liczba tłumaczy, którzy tych przekładów dokonywali. W okresie międzywojennym „w rachubę wchodziło łącznie aż 155 tytułów" (Waksmund 1998: 239). Niestety ilość 
nie przełożyła się w tym przypadku na jakość wydań i wierność tekstów, co potwierdza Katarzyna Grzywka: „Dla okresu po pierwszej wojnie światowej znamienny jest «zalew» tanich przekładów i opracowań, często silnie odbiegających od oryginału" (Grzywka 2007: 43). Baśnie braci Grimm wydawano za pozwoleniem okupanta hitlerowskiego także w czasie drugiej wojny światowej. Do 1945 roku opublikowano w Polsce łącznie około 30 wyborów baśni Grimm przygotowanych w polskich wydawnictwach lub przejętych $\mathrm{z}$ edycji zagranicznych (por. Krysztofiak 1999: 152). Traumatyczne przeżycia wojenne i szara powojenna rzeczywistość sprawiły, że w Polsce rozgorzała debata nad szkodliwym wpływem tych baśni na umysły młodych czytelników. W prasie pojawiały się szkalujące zbiór artykuły ${ }^{3}$. Pierwsze powojenne wydanie ukazało się na polskim rynku dopiero w 1956 roku. Był to zbiór 22 baśni w przedwojennym przekładzie Marcelego Tarnowskiego i w wyborze Stefanii Wortman. Baśnie stały się obowiązkową lekturą w kanonie lektur szkolnych dla klasy czwartej i przez około 35 lat funkcjonowały jako baśnie braci Grimm, choć niewiele miały wspólnego z oryginalnymi tekstami. Wielokrotnie ukazywały się przekłady pojedynczych baśni i liczące kilkanaście baśni zbiory, ale kolejne pełne wydanie dzieli od pierwszego blisko 100 lat, ponieważ pojawiło się ono dopiero w roku 1982 roku. Była to edycja bazująca przede wszystkim na tekstach uznanego tłumacza Grimmów Marcelego Tarnowskiego, które opublikowano w 1925 roku, ale z poprawkami i uwspółcześnionymi tłumaczeniami dokonanymi przez Emilię Bielicką. Zbiór Baśnie braci Grimm opatrzono posłowiem Heleny Kapełuś i barwnymi ilustracjami Elżbiety $\mathrm{Mu}$ rawskiej. Dwa lata przed 200. rocznicą pierwszego wydania niemieckich baśni Kinder- und Hausmärchen nakładem poznańskiego wydawnictwa Media Rodzina pojawiło się na polskim rynku dwutomowe wydanie Baśni dla dzieci i dla domu w przekładzie poznańskiej germanistki Elizy Pieciul-Karmińskiej. Analizując dotychczasowe dokonania tłumaczy w tej dziedzinie, trzeba przyznać, że tłumaczka dołożyła wszelkich starań, aby oddać w ręce czytelnika wierny przekład, opatrzony jej przypisami i posłowiem, a dzięki temu pozwalający odbiorcy poznanie realiów XIX-wiecznych Niemiec. Tuż przed Bożym Narodzeniem 2012 roku wydawnictwo REA wydało książkę Bracia Grimm. Wszystkie baśnie i legendy. „Było to o tyle zaskakujące, gdyż wspomniane wy-

${ }^{3}$ Należy tu wymienić artykuł Niemieckie bajeczki Marii Szczepańskiej zamieszczony na łamach „Przekroju” z 1945 roku, tekst Ireny Tomskiej Hitler i Grimm w „Kurierze Porannym” z tegoż roku, rozprawkę Wiesława Osterloffa Jaś i Małgosia (Próba analizy) opublikowaną w „Życiu Szkoły" w 1946 roku i kolejny artykuł tego autora Kryminalistyka i bajki Grimma na łamach „Odrodzenia” czy wiersz Tadeusza Borowskiego Życiorys dobrego Niemca (por. Waksmund 1998: 235-243). 
danie pojawiło się raptem dwa lata po innej pełnej edycji baśni braci Grimm (Baśnie dla dzieci i dla domu. Poznań: Media Rodzina), a jak dotąd pełne wydania oryginalnego zbioru baśni zatytułowanego Kinder- und Hausmärchen były w Polsce rzadkością" (Pieciul-Karmińska 2013: 58). Ta luksusowa edycja baśni, wydana na pięknym papierze i oprawiona w elegancką okładkę, jest między innymi przedmiotem niniejszego artykułu.

\section{Kilka informacji o źródłach analizy}

Przedmiotem analizy są trzy książki, z których każda jest przekładem z języka trzeciego. Pierwszą z nich są Bracia Grimm. Wszystkie baśnie i legendy wydawnictwa REA. Przedstawię tylko najważniejsze informacje dotyczące tej edycji, gdyż Pieciul-Karmińska poświęciła jej artykuł „Niebieska broda”, czyli dlaczego nie należy tłumaczyć baśni braci Grimm z języka rosyjskiego (por. Pieciul-Karmińska 2013: 58-76). W książce nie podano źródła przekładu, chociaż w przypadku literatury pięknej jest to informacja standardowa. Ponadto w przypadku baśni braci Grimm jest ona niezwykle ważna ze względu na zmiany, którym podlegały kolejne edycje. $\mathrm{Z}$ informacji podanych przez autorkę artykułu w przypisie można się dowiedzieć, że źródło przekładu stanowią Baśnie zebrane przez braci Grimm wydane przez A.F. Marksa w Sankt Petersburgu. Brakuje informacji dotyczącej roku wydania, a o przybliżonym czasie publikacji może świadczyć jedynie nota o zezwoleniu cenzury z 24 lutego 1893 roku. Dziwi więc, dlaczego Bracia Grimm. Wszystkie baśnie i legendy bazują na XIX-wiecznym przekładzie, nie biorąc pod uwagę historii recepcji baśni. Kolejnym dowodem świadczącym o rosyjskim źródle przekładu, na który wskazuje Pieciul-Karmińska, jest fakt, że tłumaczką zbioru była Rozalia Skiba, która według informacji znajdujących się w internecie jest rusycystką (por. Pieciul-Karmińska 2013: 60). O rosyjskim pochodzeniu źródła świadczą także liczne błędy językowe i translatorskie, które wiążą się między innymi z błędną transkrypcją z języka rosyjskiego. Autorka przytaczanego artykułu uważa, że działanie wydawnictwa jest zamierzone, a jego powodem są najprawdopodobniej sprawy finansowe, bo rosyjskie wydanie nie jest chronione prawami autorskimi (por. Pieciul-Karmińska 2013: 59-60).

Drugim źródłem mojej analizy są Baśnie braci Grimm w przekładzie z języka węgierskiego, wydane przez wydawnictwo Jedność w 2010 roku. Jest to zbiór 28 wybranych baśni w przekładzie Szymona Budzowskiego. W książce podano wprawdzie tytuł węgierskiego oryginału, ale zabrakło informacji, jakie było źródło przekładu na język węgierski. Edycja jest bogato ilustro- 
wana, można nawet stwierdzić, że ilustracje stanowią większą część książki niż tekst.

Trzecim źródłem jest książka Baśnie braci Grimm dla dorosłych i młodzieży Philipa Pullmana w przekładzie z angielskiego Tomasza Wyżyńskiego. W Bibliografii poinformowano, że niemieckim wydaniem baśni, z którego korzystał autor, jest siódma edycja Kinder- und Hausmärchen, którego obecnym wydawcą jest Wilhelm Goldmann Verlag (por. Pullman 2014: 23). Książka zawiera 50 wybranych przez Pullmana baśni, które zostały przez niego opatrzone notami o typie baśni, źródle jej pochodzenia i podobnych baśniach. We Wstępie autor przedstawia motywy napisania książki, dokonane przez niego zmiany oraz ich przyczyny: „W niniejszej książce zamierzałem przedstawić najlepsze, najciekawsze z nich [czyli baśni], oczyszczając je ze wszystkiego, co utrudnia swobodny bieg narracji. Nie chciałem ich umieszczać we współczesnej scenerii, tworzyć osobistych interpretacji ani poetyckich wariantów oryginałów, lecz chciałem po prostu napisać wersje czyste jak woda" (Pullman 2014: 11).

\section{Analiza tytułów i treści przekładów}

W niemieckiej baśni Wilk i siedem koźlątek pojawia się ironiczne zdanie podsumowujące ludzką naturę, kiedy młynarz ze strachu pobielił wilkowi łapy, mimo że domyślał się jego złych zamiarów. Brzmiącą w oryginale konstatację „Ja, das sind die Menschen” (Grimm 1984: 52) Pieciul-Karmińska przetłumaczyła jako „Tacy właśnie są ludzie” (Grimm 2010a: 38), co w moim przekonaniu idealnie oddaje zamiar autorów sformułowania uniwersalnego, filozoficznego przesłania. W przekładzie Rozalii Skiby zdanie przetłumaczone jako „Cóż, tacy ludzie też bywają na świecie” (Grimm 2012: 43) traci swoją wymowę i nie dotyczy już ogólnych zachowań ludzkich, ale postępowania jednej konkretnej osoby. W baśniach w przekładzie Szymona Budzowskiego nie ma śladu tego zdania. Trudno wyjaśnić, co było powodem jego usunięcia. Być może tłumacz uznał, że w edycji adresowanej wyłącznie do dzieci jest ono zbędne, bo trudne do zrozumienia przez najmłodszego czytelnika, a może zdanie to nie pojawiło się w węgierskim przekładzie i dlatego nie zostało przełożone na język polski.

W baśni O rybaku i jego żonie tytułowy rybak wyławia z morza ogromnego turbota (po niemiecku der Butt), jednak takie tłumaczenie tego leksemu pojawia się tylko u Pieciul-Karmińskiej. W przekładzie Rozalii Skiby czytamy o „złotej rybce”, która według poznańskiej tłumaczki wynika z tego, że „złota 
rybka przeniknęła do tradycji polskich przekładów za sprawą Puszkinowskiej złotej rybki" (Pieciul-Karmińska 2013: 72). Prawdopodobnie w rosyjskim wydaniu XIX-wiecznym tłumacz dostosował przekład do rosyjskiej kultury, zamieniając turbota na złotą rybkę, a tłumaczka z rosyjskiego nie zweryfikowała tego tłumaczenia $\mathrm{z}$ oryginałem ani $\mathrm{z}$ istniejącymi już $\mathrm{w}$ języku polskim przekładami. O ile złota rybka utrwaliła się w tradycji polskich przekładów, o tyle dziwi „wielka flądra” (Pullman 2014: 123) w książce Pullmana. Turbot $\mathrm{w}$ literaturze niemieckiej jest bowiem pewnego rodzaju symbolem i jasnym nawiązaniem do legendarnej ryby z bajki Grimmów ${ }^{4}$.

W polskich przekładach nie utrwaliła się druga część bajki Czerwony Kapturek. W polskich przekazach zazwyczaj kończy się ona nafaszerowaniem wilka przez myśliwego kamieniami i śmiercią wilka, tymczasem w oryginale inny zły wilk próbuje ponownie zwieść dziewczynkę z drogi. Tym razem jednak tytułowy Czerwony Kapturek, nauczony doświadczeniem, jest ostrożny i nie ulega namowom wilka. Gdy wilk pojawia się w pobliżu domu babci, tonie w korycie - zasadzce przygotowanej przez babcię i dziewczynę. Wersja rozszerzona znajduje się w przekładach Emilii Bielickiej i Elizy Pieciul-Karmińskiej, jednak nie ma jej ani w Baśniach braci Grimm dla dorostych i młodzieży, ani w książce Bracia Grimm. Wszystkie baśnie i legendy. To zaskakujące, zwłaszcza w przypadku edycji wydawnictwa REA, które pokusiło się o wydanie wszystkich 200 baśni i 10 legend, dotychczas niepojawiających się w pełnych przekładach ${ }^{5}$, a nie postarało się o wierne przetłumaczenie oryginalnego tekstu Czerwonego Kapturka. W przypadku przekładu poprzez język pośredni trudno jednoznacznie stwierdzić, czy skrócenie bajki wynika $\mathrm{z}$ zaniechania tłumacza, czy też z takiej jej wersji w języku drugim (w tym przypadku rosyjskim), z którego dokonano przekładu na polski.

Pewne nieścisłości $\mathrm{w}$ porównaniu $\mathrm{z}$ oryginałem pojawiają się również w przypadku tłumaczenia tytułów baśni. Często są one w przekładach z języka trzeciego niezgodne $\mathrm{z}$ oryginałem lub $\mathrm{z}$ treścią, co jest konsekwencją przekładu z języka trzeciego, ponieważ przekład z przekładu nigdy wiernie nie odda pierwowzoru.

${ }^{4}$ Turbot pojawił się między innymi w tytule jednej z powieści Güntera Grassa, którą wydano w Niemczech w 1977 roku, a która ze względów politycznych bardzo długo nie była publikowana w Polsce, ponieważ jednym z wątków są wydarzenia z Grudnia 1970 roku na Wybrzeżu, kiedy strzelano do protestujących robotników Stoczni Gdańskiej. Turbot z książki Grassa jest nawiązaniem do Grimmowskiej baśni.

${ }^{5}$ Katarzyna Grzywka i Ryszard Waksmund podają informację świadczącą o tym, że jedynie pierwsza pełna edycja z 1896 roku w przekładzie Zofii Antoniny Kowerskiej zawierała 10 legend (por. Grzywka 2007: 43; Waksmund 1998: 239). 
Niemiecka baśń zatytułowana Der Teufel mit den drei goldenen Haaren opowiada historię urodzonego w czepku chłopca, któremu przepowiedziano, że w czternastym roku życia poślubi córkę króla. Król, dowiedziawszy się o tym, postanawia pozbyć się potencjalnego zięcia, a kiedy mu się to nie udaje, stawia przed nim niewykonalne zadanie, polegające na przyniesieniu trzech złotych włosów diabła. W baśniach Grimmów liczby nabierają magicznego charakteru, dlatego często pojawiają się już w tytułach. Najczęściej są to: trzy, sześć, siedem, dziesięć oraz dwanaście. W przytaczanej bajce liczba trzy ma znaczenie, bo chłopak musi zdobyć trzy włosy i odpowiedzieć na trzy pytania, żeby otrzymać królewnę za żonę. W przekładzie z węgierskiego tytuł brzmi Złote włosy diabła i nie pojawia się $\mathrm{w}$ nim magiczna liczba. W przekładzie $\mathrm{z}$ angielskiego trudno wywnioskować, do kogo należą tytułowe trzy włosy, dlatego że tytuł brzmi Diabeł i trzy złote włosy. Według mnie podkreśla on pewną odrębność diabła i trzech złotych włosów. W przekładzie Pieciul-Karmińskiej tytuł ten brzmi Diabeł o trzech złotych włosach, a w przekładzie Bielickiej Bajka o diable z trzema złotymi włosami, co dowodzi podobieństwa tłumaczenia. Różnice w przekładach z przekładów są konsekwencją tłumaczenia poprzez langue pivot - najprawdopodobniej tytuły te zostały zmienione w pierwszym przekładzie i powielone w następnym. To kolejny dowód na to, że tłumacze dokonujący przekładu niebezpośrednio $\mathrm{z}$ oryginału nie sięgnęli w celu porównania ani do pierwowzoru, ani do polskich przekładów. Ponadto w oryginale tej baśni wyraźnie zaznaczono, że chłopiec miał szczęście, bo był w czepku urodzony „weil es eine Glückshaut um hatte” (Grimm 1984: 167). W tłumaczeniu z węgierskiego darmo szukać tej informacji, natomiast w przekładzie z angielskiego syn ubogiej kobiety „urodził się w czepku”, co jest niedokładnym przekładem na język polski związku frazeologicznego, który w formie poprawnej ma postać „być w czepku urodzonym”.

W oryginale chłopcu pomaga babka diabła (Ellermutter) ${ }^{6}$, która zamienia go w mrówkę, ukrywa w fałdach swojej spódnicy i dla niego wyrywa diabłu trzy złote włosy. W tłumaczeniu $\mathrm{z}$ węgierskiego pojawia się natomiast matka diabła. Taki przekład może wskazywać na niedostateczną znajomość języka niemieckiego i jego regionalnych odmian lub niewierny przekład na język węgierski. Poza tym stanowi pewne zafałszowanie treści oryginału.

W oryginale tytułu baśni Die zertanzten Schuhe widzimy przymiotnik określający buty. W tytułach przetłumaczonych na język polski przez Bielicką i Pieciul-Karmińską użyto dla niego ekwiwalentu stańcowane - obie tłumacz-

${ }^{6} \mathrm{~W}$ dialekcie dolnoniemieckim (Niederdeutsch) słowo Ellermutter lub Eldermutter jest synonimem słowa Großmutter- babcia. 
ki zgodnie zatytułowały baśń Stańcowane pantofelki. W przekładzie z języka rosyjskiego tytuł brzmiący Zniszczone trzewiki nie ma odniesienia ani do tytułu oryginału, ani do treści baśni. Tytułowe buty należą do dwunastu królewien, które potajemnie wymykają się nocą ze swej zamkniętej komnaty na tańce $\mathrm{z}$ dwunastoma książętami; rano przed ich drzwiami stoją zniszczone od tańców buty. W baśniowej tradycji królewny i księżniczki noszą pantofelki, dlatego leksem trzewiki nie odpowiada tej baśniowej konwencji. Ponadto przymiotnik zniszczone jest zbyt ogólny i nie nawiązuje do motywu baśni. $\mathrm{W}$ przekładzie z języka angielskiego tytuł brzmi Pantofelki zdarte od tańca i wprawdzie odnosi się do głównego wątku, ale jest zbyt opisowy i dlatego daleki od konwencji pierwowzoru. Oryginalne tytuły baśni są bowiem krótkie i proste.

Z różnic systemowych pomiędzy językiem polskim i angielskim wynika kolejny błąd translatorski, będący konsekwencją przekładu poprzez język pośredni. „W języku polskim uosobiona śmierć jest rodzaju żeńskiego, w języku angielskim - męskiego" (Brajerska-Mazur 2007: 197). W języku niemieckim spersonifikowana śmierć jest rodzaju męskiego, dlatego tytuł oryginału brzmi Der Gevatter Tod (Ojciec chrzestny śmierć - tłum. A.Z.). Tłumacz z języka angielskiego przetłumaczył tytuł jako Śmierć ojcem chrzestnym, co jest niezgodne z zasadami gramatycznymi języka polskiego, bo skoro śmierć w języku polskim jest rodzaju żeńskiego, to nie może być ojcem chrzestnym, co najwyżej matką chrzestną. Zarówno w tłumaczeniu Bielickiej, jak i Pieciul-Karmińskiej tytuł ten brzmi Kuma Śmierć, co odpowiada zasadom systemu języka polskiego. Kuma według Innego słownika języka polskiego to między innymi "matka chrzestna naszego dziecka lub matka naszego chrześniaka albo naszej chrześniaczki” lub „kobieta, z którą podawaliśmy dziecko do chrztu" (Bańko 2000: 732).

Omówiony powyżej błąd jest konsekwencją przekładu z języka pośredniego, w tym przypadku $\mathrm{z}$ angielskiego, i dowodem braku znajomości polskiej tradycji przekładowej baśni braci Grimm. Gdyby tłumacz przyjrzał się wcześniejszym polskim przekładom tej baśni, uniknąłby tego translatorskiego potknięcia.

\section{Wnioski}

W świetle przytoczonych przykładów można jednoznacznie stwierdzić, że tłumaczenie baśni braci Grimm poprzez język pośredni powoduje liczne błędy wynikające z różnych czynników, między innymi braku znajomości języ- 
ka i kultury oryginału, różnic systemowych między językami, nieznajomości historii polskich przekładów lub nawet ich ignorowania. Winą za powstałe błędy nie należy jednak obarczać tylko tłumaczy. Przede wszystkim należy mieć pretensje do wydawnictw, które wpadły na absurdalny pomysł dokonywania przekładu niebezpośrednio z języka oryginału, ale poprzez języki trzecie. Winy należy też szukać wśród korektorów i redaktorów, którzy pozwolili na wydanie książek z przytoczonymi przeze mnie błędami. Uważam, że niedopuszczalne jest oddawanie wydań baśni braci Grimm w ręce najmłodszych czytelników z takimi błędami. Być może wciąż jeszcze pokutuje wśród wydawców przekonanie, że jest to czytelnik mało wymagający, który nie jest świadom błędów przekładowych, dlatego tłumaczenie nie musi być idealne. Musi być jednak przede wszystkim wolne od tego rodzaju usterek, ponieważ zadaniem książki jest między innymi rozwijanie kompetencji językowych i poprawnego użycia języka. Przytoczone przykłady powinny stanowić również naukę dla przyszłych tłumaczy baśni, aby w swej pracy korzystali przede wszystkim z tekstu oryginału, sięgali po przekłady wcześniejszych tłumaczy w celu ich porównania, starannie i rzetelnie podchodzili do powierzonego im zadania i oprócz zgłębiania tekstu źródłowego dotarli także do tekstów dotyczących tłumaczonego dzieła. Wymaga to również zaangażowania ze strony innych osób biorących udział w projekcie przekładu. Tłumaczowi powinno zależeć na uznaniu jego pracy przez czytelników, redaktorowi, aby tekst był wolny od błędów, a wydawcy na wysokiej jakości książki, by sprzedawała się w dużej liczbie i przynosiła mu zysk.

\section{Bibliografia}

\section{Literatura prymarna}

Grimm, J. i W., 1984, Kinder- und Hausmärchen, Reclam, Stuttgart.

Grimm, J. i W., 1982, Baśnie braci Grimm, tłum. E. Bielicka, M. Tarnowski, Ludowa Spółdzielnia Wydawnicza, Warszawa.

Grimm, J. i W., 2010a, Baśnie dla dzieci i dla domu, tłum. E. Pieciul-Karmińska, Media Rodzina, Poznań.

Grimm, J. i W., 2010b, Baśnie braci Grimm, tłum. Sz. Budzowski, Jedność, Kielce.

Grimm, J. i W., 2012, Bracia Grimm. Wszystkie baśnie i legendy, tłum. R. Skiba, REA, Warszawa.

Pullman, P., 2014, Baśnie braci Grimm dla dorosłych i młodzieży, tłum. T. Wyżyński, Albatros, Poznań. 


\section{Literatura sekundarna}

Bańko, M. (red.), 2000, Inny słownik języka polskiego, t. 1, Warszawa.

Białkowska, B., 1971, Baśnie braci Grimm. (Katalog wystawy), Warszawa.

Brajerska-Mazur, A., 2007, „Personifikacja śmierci w języku polskim i angielskim jako problem tłumaczeniowy”, [w:] Język a komunikacja 18. Wspótczesne kierunki analiz przekładowych, M. Piotrowska (red), Kraków, s. 197-208.

Grzybek, J., 2008, „Język angielski i język niemiecki jako języki pivot w chińsko-polskim oraz polsko-chińskim tłumaczeniu umów najmu, dzierżawy oraz leasingu", [w:] Rocznik Przekładoznawczy. Studia nad teoria, praktyka i dydaktyka przekładu, t. 3/4, s. 67-79.

Grzywka, K., 2007, „«W przestrzeni bowiem nie tylko żyjemy, ale i ,myślimy nią»». O funkcjonowaniu bajki ludowej w przestrzeni kulturowej”, [w:] Studia Niemcoznawcze, t. XXXIV, L. Kolago (red.), Warszawa, s. 39-50.

Hałub, M., 1986, „Die Märchen der Brüder Grimm in Polen”, [w:] Brüder Grimm Gedenken, Bd. 6, L. Denecke (red.), Marburg, s. 215-240.

Hałub, M., 1998, „Habent sua fata libelli. Główne tendencje w recepcji baśni braci Grimm na świecie", [w:] Orbis Linguarum. Legnickie Rozprawy Filologiczne, Vol. 10, Legnica, s. 227-243.

Krysztofiak, M., 1999, Przekład literacki a translatologia, Poznań.

Pieciul-Karmińska, E., 2011, „Polskie dzieje baśni braci Grimm”, [w:] Przekładaniec, nr 22-23 (2/2009-1/2010), Kraków, s. 80-96.

Pieciul-Karmińska, E.,2013, „«Niebieska broda», czyli dlaczego nie należy tłumaczyć baśni braci Grimm z języka rosyjskiego", [w:] Język. Komunikacja. Informacja, t. 8, I. Kountny, P. Nowak (red.), Poznań, s. 50-76.

Pleciński, J., 2015, „Zabawa trwa w najlepsze, czyli języki A, B i C w przekładzie", [w:] Rocznik Przekładoznawczy. Studia nad teoria, praktyka i dydaktyka przekładu, t. 10, s. 139-150.

Seitz, G., 1984, Die Bruder Grimm: Leben, Werk, Zeit, München.

Simonides, D., 1989, „Jakub i Wilhelm Grimmowie a folklor polski”, [w:] Bracia Grimm i folklor narodów słowiańskich. Materiały z międzynarodowej konferencji (Warszawa 18-19 listopad 1985), J. Śliziński, M. Czurak (red.), Wrocław, s. 24-50.

Sumera, A., 2000, „Source language, target language and the third one”, [w:] Przekładając nieprzekładalne. Materiały z I międzynarodowej konferencji translatorycznej Gdańsk-Elblag, W. Kubiński, O. Kubińska, T. Wolański (red.), Gdańsk, s. 537-542.

Waksmund, R., 2000, Od literatury dla dzieci do literatury dziecięcej, Wrocław. Waksmund, R., 1998, „Sąd nad baśniami braci Grimm w polskiej krytyce li- 
terackiej 1945-1949", [w:] Orbis Linguarum. Legnickie Rozprawy Filologiczne, Vol. 10, Legnica, s. 235-243.

Woźniak, M., 2011, „Jak to z «Kotem w butach» było. Baśnie Charles’a Perrlauta w przekładzie..., [w:] Przekładaniec, nr 22-23 (2/2009-1/2010), Kraków, s. 60-79.

\section{A few words about why the Grimms' fairy tales should not be translated through a third language}

\section{Summary}

The article discusses the translation of the Grimms' fairy tales into Polish through a third language. The author analyses translations from English, Hungarian and Russian, and indicates some mistakes and shortcomings which appear as a result of interpreting the translation and not directly the Grimms' works. Translation through a third language also causes the loss of cultural elements characteristic of the German original since the cultural reality found in the first translation was adapted to the recipient of a target text.

Keywords: original language, language pivot, intermediate language, mistakes in translation, Grimms' fairy tales 